UDC 537.312.62:534.321.9:537.624.4

\title{
超電導導体 $(\mathrm{Nb}-\mathrm{Ti})$ の磁化過程および通 電過程に打汀超音波放出の研究
}

\begin{tabular}{|l|}
\hline 論 文 \\
\hline $55-\mathrm{A} 26$ \\
\hline
\end{tabular}

\author{
正員 野 村 晴 彦 (電総研)
}

\section{1.はじめに}

超電導電磁石は，核融合，MHD 発電，高エネルギ 一技術および磁気浮上列車の分野などでは不可欠なる のであるがててれらの電磁石はその蓄䅣エネルギーが 数 GJ 級に及ふ心で，天の安全性は十分研究される必 要肪るるそのためには，かかる大土ネルギー容量の 電磁石がいかなる磁化状龍にあるかを的確化はあくす る監視技诲の问上が極めて重要となる。従来，主に監 視法として用いられているのは䉓磁西の端子電生の㛟 知があるが，その蓄積エネルギーの巨大化につれて目 己誘賏す大きくなり，電酸石に必然的に生じる磁束の 不規則な動きに起因する発生電生は端子電持の雑音之 して観测されるとこる上なり，電正测定の歩止まりを 覀くさせる。更に，核融合用の電磁石の場合，抵坑加

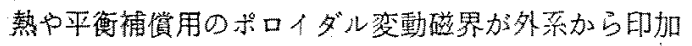
され，それに信う相互誘導電王は更に監視を複雑にす るL，MHD 発電用電磁石心場合，電磁流体の摄勡に よる電压によって観测電王はじょう乱を受け，電圧法

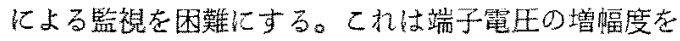
增してむ雑音もそれだけ広加るので，本質的な解決に はならない。また，乙れらの電生法ては磁浮上列草

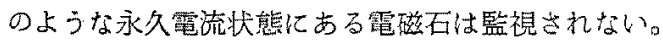
加つて筆者らは，乙の上うな電压梌知亡は全く独立 な観測系で，加つ超電煘電磁石に適した監視法はない

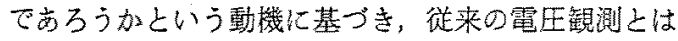
全く独立なアコースデクエミッション (Acoustic Emission：音響放出，以下 $\mathrm{AE}$ 上略記）法に上万超電 導電磁石の観测が可能であるととを見いだしだ(12)。

Acoustic Emission in a Superconductor (Nb-Ti) During Ma. gnetic Field and Current Sweep. By Harehiko Nomura, Mem. ber (Electroteclinical Laboratory, Ministry of International

Trade and Industry).

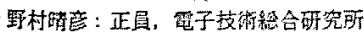

しかし，具体的にこれらの音響（一般には超音波）が 笔磁石のどこから放出されているのかは必ずしす明確 になっていなかった。もちろん，音響放出の原因は多 種考えられる。例えば，電磁石の線材や構造材の微小 動により発生するし，電・磁気力に上る微小な塑性室 形による放出や，更に超電導体内のピン止め中心など の微細構造加ら，磁束の運動状態に伴う音響放出む考 えられる。特に我々は，放出される音響振動数が数百 $\mathrm{kHz}$ 红及ぶこと加ら，超電尊体内口微細構造加磁 化過程代関連して音響放出が生じているとする点阔関 心を集中した。本諭文は，乙の観点に立って前者の外

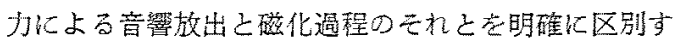
るため，超電導導体の短線試料を支持材に確害に固定 し，線材が動加ない上うにしてなされた寒験に基つい て構成されている。

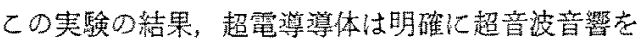
放出しており，乙れは超電導体の磁化週程と強い相関 があることが確認されだ。また，乙の放出强度を計測 することによっで試料の磁化状堵が観測され，また通

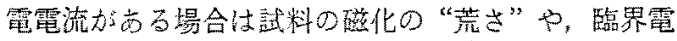
流の状態方精度良く测定されたので，理諭的湌討克交 えて報告したい。

\section{2. 実験装犆および測定法}

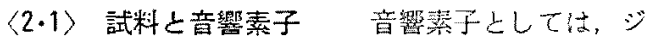
ルコン酸・チタン酸鉛 (PZT) 老用い，その形状は円板 状（直徍 $8 \mathrm{~mm}$, 厚さ $1.5 \mathrm{~mm}$ ) である。これ在第 1 困仁示すように，一つは超電導導体に，更に高純度銅 (超電導導体加ら私 $10 \mathrm{~cm}$ ) 体上に，更的う一つは電 流りード上に取り付けた。てれは，超電導賟体から発 せられた $\mathrm{AE}$ がどのへんまで伝搬されるかを見るため である。これらの素子は，感度としては一応 $10 \mathrm{kHz}$

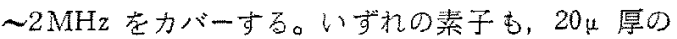




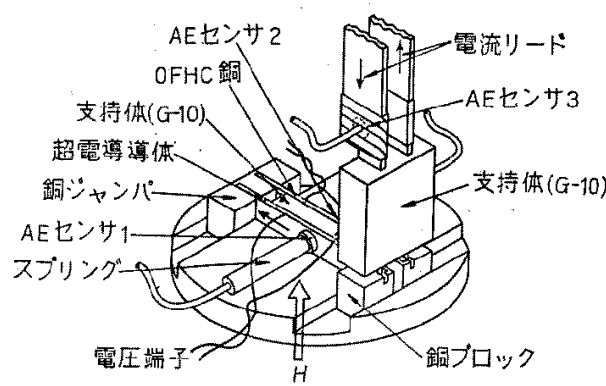

第 1 図 試験装置（超笔導体とAE センサ）

Fig. 1. Sample holder, showing in particular, the strip and acoustic emission sensors.

雲母を介して前述の位置にバネで亘接圧接した。雲母 を介したのは電気絶縁と音響結合を良くするためであ る。被擞定超電導体としては Nb-50\% Ti の多心材で あり,かつこの導体は SC : Cu の断面積比 $=1: 4.4$ で あり, 断面形状は方形 $(10.85 \mathrm{~mm} \times 0.19 \mathrm{~mm})$ 状で, 超電尊心線は約 $50 \mu \mathrm{m}$ 径のものが 200 本, $2.5 \mathrm{~cm}$ の ピッチをなして銅 $\left(\rho=1.4 \times 10^{-10} \Omega \cdot \mathrm{m}\right)$ に埋設され たもので，試料長は $12 \mathrm{~cm}$ にとった。超電導体には， 中心部汇電仕端子を $3 \mathrm{~cm}$ の間隔をあけてはんだ付け した。導体は繊維強化プラスチック（G-10）に確寒 に固定してあり、ローレンッカによって線的は動かな い。

〈2.2〉 測定系 測定系の構成図を第 2 図に示す。 すなわち，(1)の超電導短線試料内で放出された微小音 響は，試料汇直接取り付けられた $\mathrm{AE}$ 素子によって微 小な圧電信号に変換され，(2)のプリアンプで 25〜35 $\mathrm{dB}$ 増幅される。とのアンプ出力の一方は增幅器 (3)に 入り，とれを経てスペクトラム，アナライザ(Textronix, 7L5) (4)にて AE の振勤数の帯域を知る。ことで は信号も雑音む混在しているが，ててで知り得た信号 の带域によって次の(5)带域フィルタの帯域幅が決定 される。こ机によって雑音加効果的に除去され，感度 良く(6)主增幅器で 30〜50 dB 程度更に増幅される。

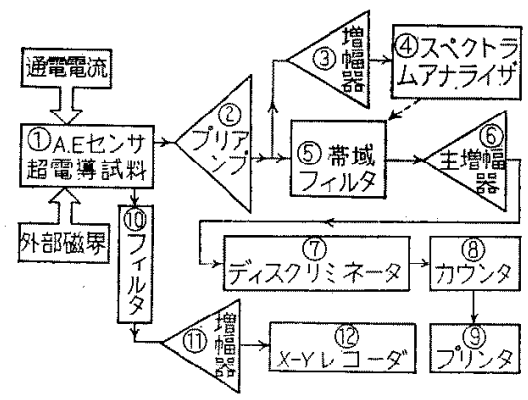

第 2 図 测定構成図

Fig. 2. Circuit block diagram.

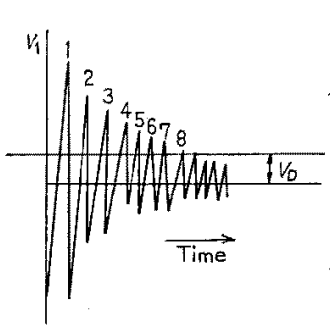

(a) (b)

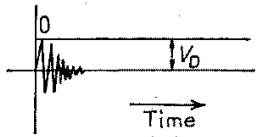

(c)

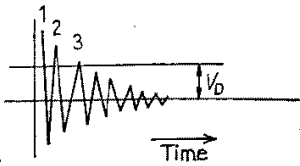

第3 图音響パワ振幅波形と $\mathrm{AE}$ 計数。 しきい值 $V_{D}$

Fig. 3. Acoustic signals relative to discrimination level $V_{D}$.

この出力は(7)のディスクリミネータに通される。この ディスクリミネータは, (8のカウンタの計数のベース を決める重要な役割を果たす。カウンタによって計数 された AEは，(9)のプリンタで每 0.5 梨でとに計数が 印字されるようにした。更に，超電導導体は端子電圧 によっても監視された。すなわち，(10のフィルタにて

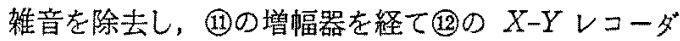
にて $0.5 \mu \mathrm{V} / \mathrm{cm}$ の感度で記録された。

これらの奏験では，印加された磁界は M.I.T., Francis Bitter National Magnet Laboratory の水 冷電磁石によって行なわれた。磁界屾比較的簡単に運 転されるが，常電導電磁石のため電磁誘導䧴音む相当 大きく，更に水流による音響雑音も大きい環境で行な われた。そのためにディスクリミネータ上带域フィル タは慎重佂設定されたディスクリミネ一タのしきい值

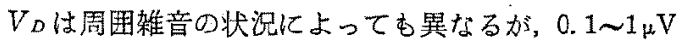
の感度で決めた。用いた計数カウンタの計数能力は $10^{6}(1 / \mathrm{s})$ であるので，第3図のように，放出された音 響波形が(a)図のような場合には 8 が，(b)図の場合 は3が計数され，(c)図のように信号がしきい值 $V_{D}$ を越えない場合はカウントされない。このように，計 数はアコースティックエミッションの強度に比例して 計数されるようにした。

\section{3. 実験}

〈3・1〉磁界掃引と AE 超電導体加ら真に音響 放出があるかを観察するために，通電電流を流さずに 外部问加磁界の掃引と AEとの関係老調へた。このと き，超電導体には磁化化伴いしへい電流加対になっ て発生するが，それは常に反対向きであるので磁束に 俥くローレンッ力む常に反対で，外部加らは観察され ない。

実験は繰返して行なわれたが，第 4 図には処女磁界 掃引時の結果を示す。（a）罒は磁界上昇掃引時，（b) 


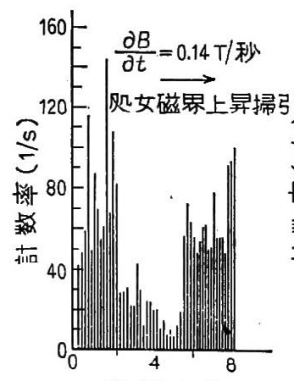

磁界 $(T)$

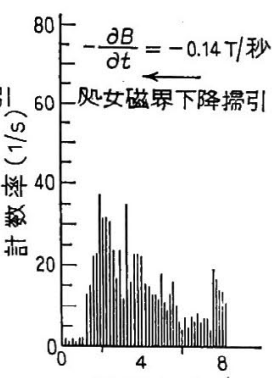

磁界 $(T)$

(b)
第 4 図処女磁界上昇掃引時 (a)および処女 磁界下降掃引時 ( b ) の $\mathrm{AE}$ 計数率

Fig. 4. Acoustic emission with virgin field sweep-up, (a) and sweepdown (b).

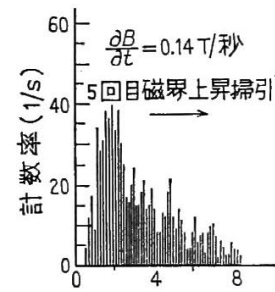

磁累 $(T)$

(a)

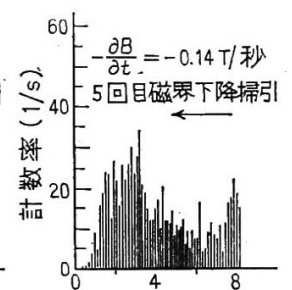

磁界 $(T)$

(b)
第 5 図磁界上昇掃引 5 回目のとき(a) 抢よび 磁界下降掃引 5 回目の之き (b)の $\mathrm{AE}$ 計数率

Fig. 5. Acoustic emission with field sweepup (a), the 5 th time, and sweep-down (b).

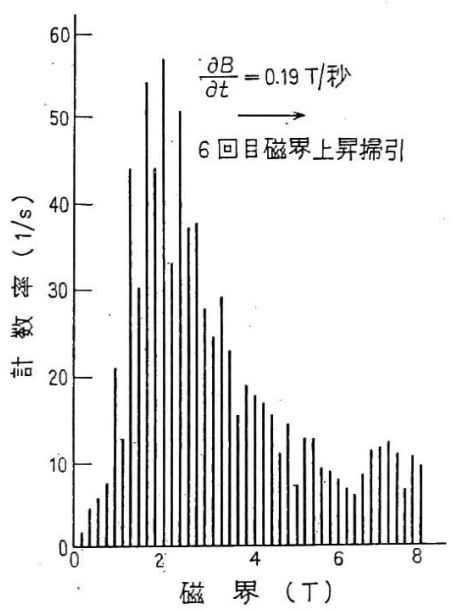

第 6 図 掃引速度を速 $<(d B / d t=0.19, \mathrm{~T} / \mathrm{s})$ した場合の $\mathrm{AE}$ 計数率

Fig. 6. Acoustic emission in fast field sweep $(d B / d t=0.19 \mathrm{~T} / \mathrm{s})$.

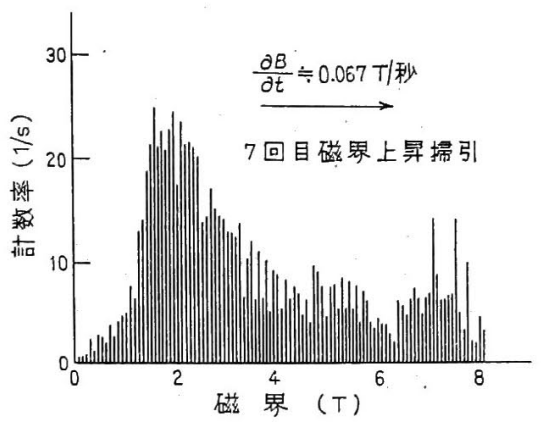

第 7 図 掃引速度在遅く $(d B / d t=0.067 \mathrm{~T} / \mathrm{s})$ した場合の $\mathrm{AE}$ 計数率

Fig. 7. Acoustic emmission in slow field sweep $(d B / d t=0.067 \mathrm{~T} / \mathrm{s})$.

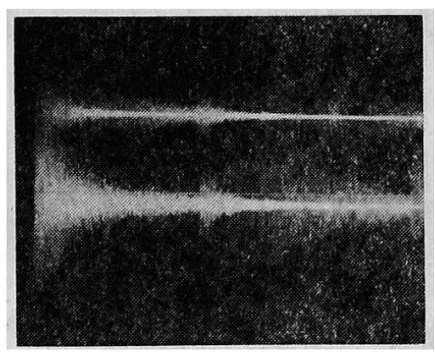

第 8 図 使用した超電導導体の中から観測 されたバースト波形(フルスケール500 $\mu \mathrm{s}$ )

Fig. 8. The photograph of the burst wave observed from in the superconductor.

図は磁界下降掃引時のときの計数率 (計数/s) を示して いる。乙れらの実験は磁界掃引速度 $|d B| d T \mid=0.14$ $\mathrm{T} / \mathrm{s}$ で行なわ机た。掃引の 2 回目からは $\mathrm{AE}$ のカウ ントはレベルがほぼ半分に減り，回を重ねてむほほ同 様の計数傾向が観測された。第 5 困に 5 回目の磁界掃 引時の計数特性を示す。

次に，磁界掃引速度と $\mathrm{AE}$ との相関を見るために， 6 回目には掃引速度を速く $(d B / d t \fallingdotseq 0.19 \mathrm{~T} / \mathrm{s})$ した結 果を第 6 図に，遅く $(d B / d t \fallingdotseq 0.067 \mathrm{~T} / \mathrm{s})$ した結果を 第 7 図に示す。結果加ら, 計数率はほほ掃引速度に. 比 例しているととが理解される。

これらの実験中， $\mathrm{AE}$ の波形解析むなされた。超電 導体から発生する波形は振幅は大小様々であるが，第 8 図の写真のように減衰振動形であり，てれらの周波 数はほほ一定で, 本超電導導体の場合, 第 9 図のよう に周波数主成分を $250 \mathrm{kHz}$ 近傍にすつバースト状の 音波であった（中央ドットは $250 \mathrm{kHz}$ を示し，横軸 1 div あたり $50 \mathrm{kHz}$, 感度 $5 \mu \mathrm{V} / \mathrm{div}$, 掃引周期 $10 \mathrm{kHz}$ )。

〈3·2〉 定磁界における通電電流と $\mathbf{A E}$ 外部磁 界を一定 (8.5T) にした後, 外部から通電電流を常電 導転移電圧が $1 \mu \mathrm{V}$ 以上試料に観測されるまで通電 


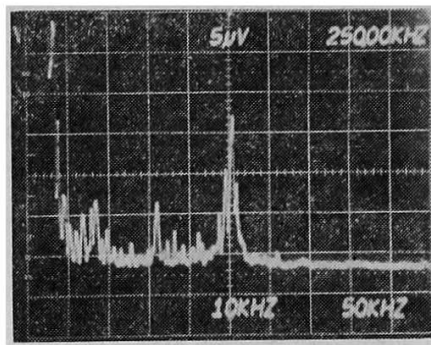

横軸 1 div $=50 \mathrm{kHz}$ ，縦刺 1 div $=5 \mu \mathrm{V}$

第 9 図 バースト波形の周波数解析

Fig. 9. photograph of the wave analysis of the bursts.

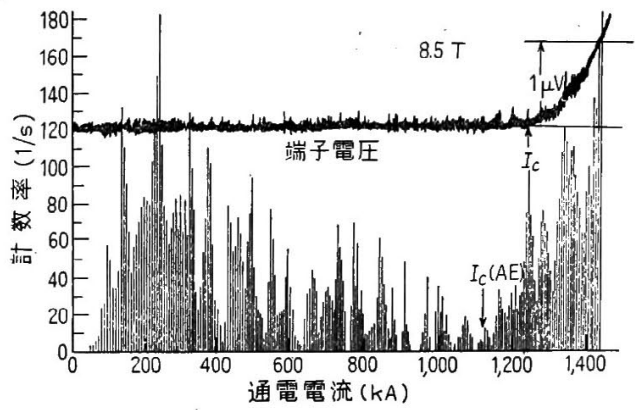

第 10 図 処女通電上昇時に得られた $\mathrm{AE}$ 計数率と試料端子電圧

Fig. 10. Acoustic emission and the terminal voltage with sweeping transport current in a virgin state.

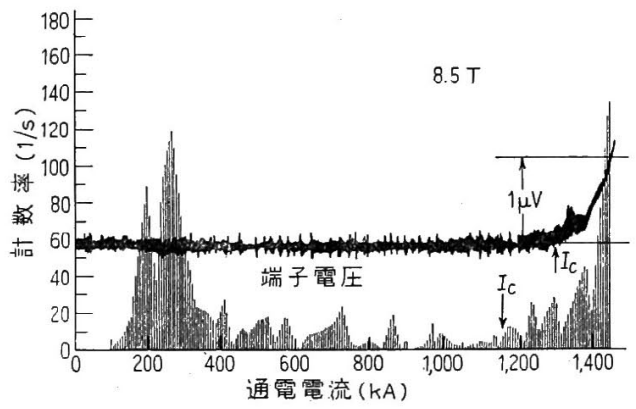

第 11 図 第 3 回目通電上昇時に得ら机た $\mathrm{AE}$ 計数率と試料端子電圧

Fig. 11. Acoustic emission and the terminal voltage with sweeping transport current, the third sweep.

し，その後通電電流を 0 までもどす実験を繰返し行な った。第 10 図に処女通電の，第 11 図に 3 回目の通 電上昇時に得られた計数率を端子電圧と併せて図示す る。なお, 図中の超電導体の端子電圧の感度は $3 \times$ $10^{-12} \Omega \cdot \mathrm{cm}$ の感度に相当する。また第 12 図には処 女の全計数（積算）を，また第 13 困には 3 回目の通 電上昇・下降時の全計数を端子電圧と共に併せて記

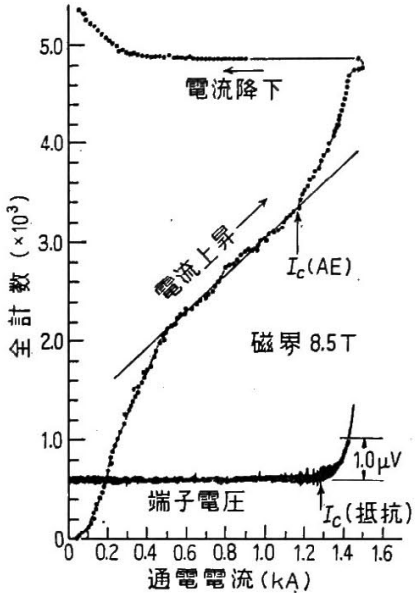

第 12 図 処女通電上昇時の通電開始からの 全計数と端子電圧

Fig. 12. Total counts and the terminal voltage with sweeping transport current in a virgin state.

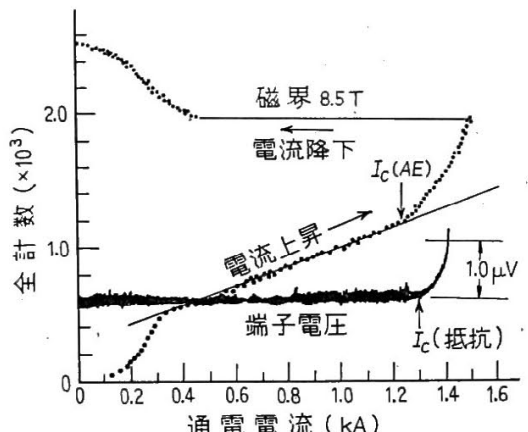

第 13 図 第 3 回目通電上昇時の通電開始 加らの全計数と端子電圧

Fig. 13. Total counts and the terminal voltage with sweeping transport current, the third sweep.

す。乙れらの一連の実験は同じ電流変化率 $(d I / d t$ $=6.25 \mathrm{~A} / \mathrm{s})$ で行なわれた。

次に，この電流変化率と計数率の関係を見るために 電流変化率を早く, あるいは遅くした場合の実験む行 なったところ，ほほ $d I / d t$ に比例した計数率が観測 された。また，磁界を変えて同様の実験をしたところ $8.0 \mathrm{~T}$ では計数率は $8.5 \mathrm{~T}$ のそれに比べて約 1.5 倍, $9.0 \mathrm{~T}$ では 0.7 倍の強度を示していた。

これらの実験の結果をまとめると，

（1）一定磁界中の通電による $\mathrm{AE}$ の計数の特徽は 非常に鋭い谷と山を形成して㧍り，処女通電時の場合 特にこれが鋭敏であり，回を重ねると鈍化する。

（2）電流掃引速度と計数率は，ほぼ比例関係にあ 
る。

(3) $8.5 \mathrm{~T}$ では $1,160 \mathrm{~A}$ 付近で $\mathrm{AE}$ の計数率に 明確な変化が見られ，挠に述べる理由からこ机は真の 臨界電流值に非常に近く，従来の電圧端子法にて常電 導電王を娭知した場合より一般的に感度が良い。

（4）処女通電時の計数蛙，それ続く計数時上り 約 3 倍大きい。

（5）計数率の違いはす机，処女通電時も非処女通 電時も $1,160 \mathrm{~A}$ 付近で計数率に大きな゙变化を見せるこ とに変わりはない。

（6）通常，通電を停留した場合，計数はほほ停止 する。

（7）ところが，特殊な点（AE 計数率が鋭いピー クを示す点に多い)で通電を停留した場合は，計数は 目立った減少をしない。すなわち，通電電流には $\mathrm{AE}$ を放出しやすい“目”の上うな点が何箅所か存在する。

（8）特に常電尊電玕出現後は，通電を下降させて いくと，ある電流值まではほとんど $\mathrm{AE}$ は計数されな い。この傾问は処女通電，非処女通電時を問利ずに観 测された。その電流值வ下に通電電流を下げていくと 計数增加傾向の AEが観测され，電流零に至るまでこ れが続く。

\section{4. 検 討}

〈4・1〉音源についての考察超電導体が，磁界 掃引すしくは通電時によ゙うして，またどてから $\mathrm{AE}$ 放出する加化ついての確実な洪乎は現在のとこるな いので，我々の実験に基ついて音源を推察するしかな い。従来の AE 理論から言えば，微細構造の微少部分 が塑性变形を起こす際に応力が解放されるとき発生

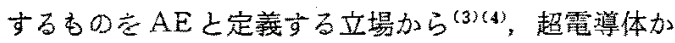
らのAEをみると，あまりにもこの定義加ら外れる点 加多い。すなわち，実駼によれば処女励磁，処女通電

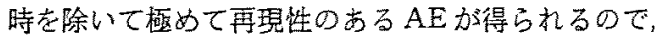
ローレンッカその李のによって塑性变形を起てしてい るとは考え難い(塑性変形によるAEならばカイザー 効果寺すはずである)。しかも外部磁界が低い所， むしくは通電電流が少小い所ですこの種の $\mathrm{AE}$ が得ら れ，てれらは再現性に富んでいる。このような点加ら して，従来の意味の“アコーステックエミッション” 上呼び得るか子疑問上するとこるである。このような 再現性のある $\mathrm{AE}$ 特性台らみて，てれらの音響放出は 超電導導体の塑性変形によるものではなく，導体の磁 化過程化伴う情伴現象之考古られる。すなわち，超電 導導体内の磁束にはローレンツカに抗するピン止め力 が戥くので，磁束がピン止め域に停留している間はこ
の忘力に伴う微小なひずみおよびてれに伴うひする の潜在エネルギーが，このピン止め域に存在している ことを意味する。磁化化伴い，磁束がピン止め域学擦 り抜けるたびにてのひずみエネルギーが解放され，乙 のときひずみ波が発生し，てれは奨体中を音速で伝搬 し表面で微小音波として観测されるとすると，大略こ の種の AE の定性的理解が得られる。次節には，てれ に多少定旺的考察を加えて熦討したい。

〈4-2〉 超電導觎体の磁化と $\mathrm{AE}$ 実呀によれば， 超電導体に外部磁界を印加するだけで $\mathrm{AE}$ が観測され ている。とれは超電導導拣の磁化過程とAEが密接に 関連していることを示している。

こてでは，超電導導体の磁化過程における $\mathrm{AE}$ 定 量的に諭じてみたい。簡単化のために，第 14 因以降

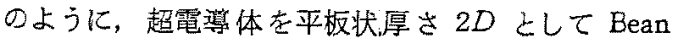
model ${ }^{(5)(6)}$ にて考察してみよう。Bean model は圈知 のように，磁北過程にかいて超電導体中の各点でちの 点の臨界電流 $J_{c}$ になるように磁束加分布するとする あのである。すなおち超電慰尊体内には，ピン止め力 に上る制限を受けて導体内に磁束密度にこう配を生 じ, Bean model によれ代導体内の磁束に加かるロー レンッ力 $F$ は次のように表わされる。

$$
F=J_{c} B=J_{c}\left\langle B_{s} \mp J_{c} x\right\rangle \text {. . . }
$$

ここで， $B$ は超電導体の垡面加ら内部に向加ってとっ た距離 $x$ の地点の磁束密度を表わし，B，は超電導体 表面の磁束密度で，乙れは外部印加磁界儿等しい。ま た負符号は磁界の上暑洔に，正符号㤬磁界の下降時に それぞれ適用する。外部磁界を上昇させる場合は，ピ ン止め力の制限を受けながら導体内部人と磁束に侵入

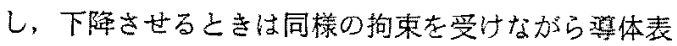
面に浸出してくる。

いずれの場合にせよ，このピン止め力に逆らって磁 束が擦り抜けるには，て机に抗して任事汃成さ机なけ ればなるない。これは，一種の摩擦力に対する仕事と 考えることができるこの力虫，ローレンッ力を $\vec{F}$ するとき，この抗力 $f_{R}$ は次式にて表わされる。

$$
f_{R}=-\eta \vec{F}
$$

$\eta$ は摩擦係数と考えられる。この $f_{R}$ の力で磁束が速 度 $\vec{V}$ て擦り枝ける之きのでパワは，次のよう网者 の皘で表わされ

$$
P=\eta \vec{F} \cdot \vec{V}
$$

(1)式を(3)式に代入して

$$
\begin{aligned}
P & =\eta J_{c} B(d x \mid d t) . \\
& =\eta J_{c}(d \phi \mid d t) \ldots . \\
& =\eta J_{c}(d|A| \mid d t) .
\end{aligned}
$$

昭 $55-4$ 
ここで， $\phi$ は超電導体中の磁束を表わし，とれは第 14 図以降示す部分の面積 $|A|$ 亿等しい。(4c)式から知 られるように，乙の面積の変化率を使ってパワが表わ される。とのパワは音響強度に比例すると考え，当実 験ではこの音響強度は計数率 $(d N / d t)$ に比例するよ うに設定されている。これは

$$
(d N / d t)=C P
$$

で表わされる。Cは第3章で述べたディスクリミネー タのしきい值で決まる定数である。とれらのパワ，あ るいは計数率は，磁界の上昇・下降時におりる磁束分 布およどローレンッ力の向きの違いから各磁化過程に 忍じて異なってくる。てれを以下過程別に表わす。

（1）処女磁界上㫒掃引時湯合の磁化は第 14 図のように進行し，てのときの磁束 $\phi$ は，

$$
\begin{aligned}
\phi & =\int_{0}^{x}\left(B_{s}-J_{c} x\right) d x \\
& =\left\{\begin{array}{l}
=B_{s}^{2} / 2 J_{c} \ldots \ldots \\
=B_{s} D-J_{c} D^{2} / 2 .
\end{array}\right.
\end{aligned}
$$

こてで, 前者は外部磁界が $B_{s}=J_{c} x \leq J_{c} D$ の範囲に あるとき，後者は $B_{s}>J_{c} D$ の範囲と皘分区間が異 なる。さて，これを使用して処女磁界上昇掃引時の 計数率 $(d N / d t)$ を求めてみる上〔ててで, $d \phi \mid d t=$ $\left(\partial \phi / \partial B_{s}\right)(\partial B s / \partial t)$ であるととに注意して)，

$$
\begin{aligned}
d N / d t & =C P \\
& =\left[\begin{array}{ll}
C \eta B_{s}\left(\partial B_{s} / \partial t\right) & \left(0 \leq B_{s} \leq J_{c} D\right) \\
C \eta J_{c} D\left(\partial B_{s} / \partial t\right) & \left(B_{s}>J_{c} D\right)
\end{array}\right.
\end{aligned}
$$

（2）磁界下降掃引時 外部磁界をいったん $B_{T}$ まで到達させて後，降下したときの $B_{T}$ 加らの磁束変 化分は，前項之同橙二つの過程で表わされ，第 15 図 のようになり

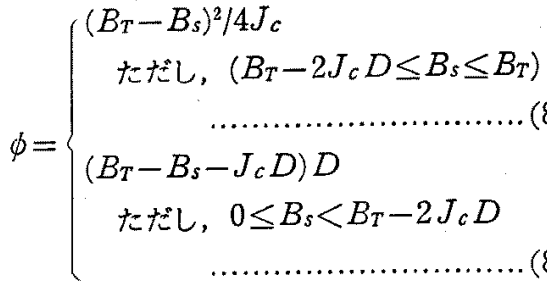

よって計数率は，それぞれ

$$
\begin{aligned}
d N / d t=C P= & (C \eta / 2)\left(B_{T}-B_{s}\right) \\
& \times\left(-\partial B_{s} / \partial t\right) \ldots
\end{aligned}
$$

ただし, $\left(B_{T}-2 J_{c} D \leq B_{s} \leq B_{T}\right)$

$$
d N / d t=C P=C \eta J_{c} D\left(-\partial B_{s} / \partial t\right) \ldots
$$

ただし， $\left(0<B_{s}<B_{T}-2 J_{c} D\right)$

（3）非処女磁界上昇掃引時外部磁界を零にし ても，導体内には第 16 図のようにピン止めによって トラップされた磁束が存在しておうり，この磁束は運動 に寄与しないととを考慮して，磁束変化量 $\phi$ は，

$$
\phi= \begin{cases}B_{s}^{2} / 4 J_{c} & \left(0<B_{s} \leq 2 J_{c} D\right) \ldots \ldots \\ \left(B_{s}-J_{c} D\right) D & \left(B_{s}>2 J_{c} D\right) \ldots\end{cases}
$$

となりよって計数率は次のようになる。

$$
\begin{aligned}
& d N / d t \\
& =\left\{\begin{array}{c}
C \eta / 2 \cdot B_{s}(\partial B / \partial t)\left(0<B_{s} \leq 2 J_{c} D\right) \\
\ldots \ldots \ldots \ldots \ldots \ldots \ldots \ldots(11 \mathrm{a}) \\
C \eta J_{c} \cdot D(\partial B / \partial t)\left(B_{s}>2 J_{c} D\right) \\
\ldots \ldots \ldots \ldots \ldots \ldots \ldots \ldots . . . \ldots \ldots \ldots \ldots
\end{array}\right)
\end{aligned}
$$

これらの結果をまとめて図示すると，第 17 図のよう な表面磁束密度 $B s$ 之計数率の関係吕得られる。

以上，超電導体の磁化過程上 $\mathrm{AE}$ の計数率の関係に ついて，磁束線がピン止め域を外れるときの拘束力之

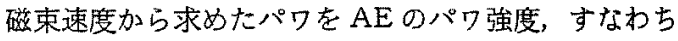
今回は計数率に対応させた結果，前章の実験結果を大

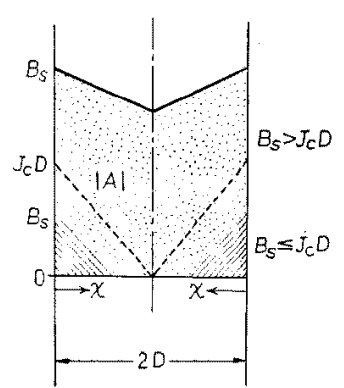

第 14 図処女磁界上昇時 の磁化過程

Fig. 14. The magetization in a virgin field sweep-up.

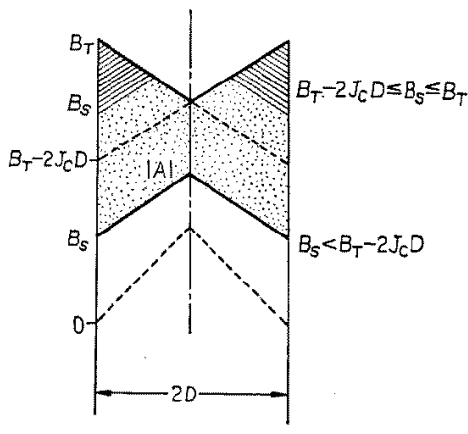

第 15 図磁界下降掃引時の 磁化過程

Fig. 15. The demagetization in sweep-down the field.

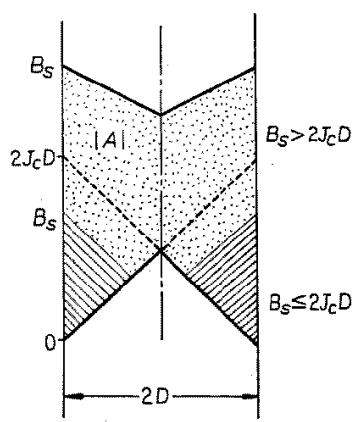

第 16 困 非好女磁界上昇時の 磁化過程

Fig. 16. The magnetization in non-virgin field sweep up. 


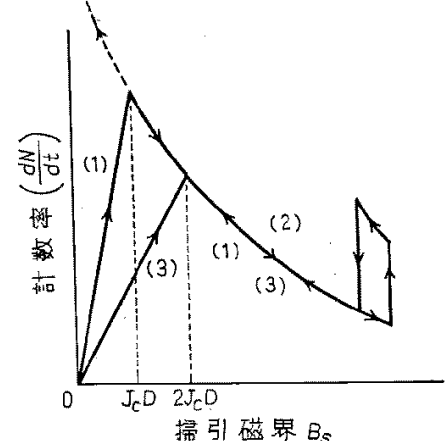

第 17 図 理論加ら得られた各磁界掃引 時に打ける表面磁束密度と計数率

Fig. 17. Counting ratio vs. $B_{s}$ in various sweeping condition from our theory.

略において説明することができる。すなわち，

（a）処女および非処女磁界上昇掃引時を比べてみ ると，処女掃引時のときはピークは $B_{s}=J_{c} D$ で, 非処 女掃引時のピーク $\left(B_{s}=2 J_{c} D\right.$ のとろ) より大きい。

（b）下降掃引時は，処女－非処女過程を問わず同 じ結果になる。また， $B_{T}-2 J_{c} D<B_{s}<B_{T}$ の範团で 大きな計数率が得られる。

(c) 磁界上昇要しくは下降速度，すなわ方 $\left|d B_{s}\right|$ $\partial t \mid$ に計数率は比例する。

(d) 計数率が $J_{c}$ 亿比例するところから，Jcの磁 界依存性が逆化計数率仙よって知られる。

次に，この理論で実験結果と大きく達うこころは，

(i) 処女上昇掃引時には，もっと不規則で大きな 計数が観測された。

(ii) 磁界下降掃引時は $J_{c}$ に比例して計数率加增 加するはずであるが，突験ではある地点（ $B_{s} \simeq 2 J_{c} D$ であるう) 以下の磁界では計数率も減少し，これは雾 磁界まで続く。

これらの不一致は，(i)項については処女磁界上昇 掃引時は導体内に打いて Bean model の上うに，ピ ン止め力は均質に分布していないためと考えられ，

（ii)項については（3)式にみる上うに，本論文の観点 が計数率はローレンッカと磁束がピン止め力を外れる ときの速度の皘に比例するとして進められているが， 実際は低磁界ではローレンッ力屯減少し，従ってその 抗力む小さくなるので，磁束のピン域を外れるときの 速度も苛る一定しきい值以下になると考えられ，ての 結果, 衝撃状の $\mathrm{AE}$ の計数が減るむのと考えられる。

$\langle 4.3\rangle$ 通電電流と $\mathbf{A E}$ 前節の理論を踏襲して 考えてみる。一定磁界 $B_{0}$ を印加して通電電流を上昇 させると，磁束の変化は
$\phi=(I / 2 a)\left(D+I / 4 a J_{c}\right)$

ただし， $a$ : 長さの単位をすつ定数

また, $d \phi / d t=\partial \phi / \partial I(\partial I / \partial t)$ であるから，計数率は

$d N / d t=C P$

$$
=(C \eta / 2 a)\left(J_{c} D+I / 2 a\right)(\partial I / \partial t)
$$

となって，これは実験結果を説明しない。すなわち， てれは計数率は電流の增加に伴って增加するはずであ るが，実験の結果は計数率が鋭敏に山と谷を有するの こぎり状を示し，(13)式のように簡単にはなってきて いない。すなわち磁界掃引の場合, 磁界0から8.5T と大きなレンジで磁束が変化するので, 磁束の変化の みで大略説明できたが，通電電流による自己磁界のレ ンジは $0 \mathrm{~A} \rightarrow 1,000 \mathrm{~A}$ です $0.054 \mathrm{~T}, 1 / 160$ 亿過ぎな い。乙の場合, 磁束の分布の変化が均一に行なわれる とする Bean model では，かかる磁柬の不規則な勤き は説明できない。

実験結果では，通電電流のほ涩 $50 \mathrm{~A}$ を周期にして 鋭いピーク状の $\mathrm{AE}$ が繰返しカウントされている。乙

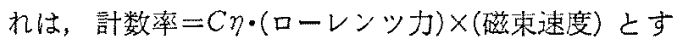
る立場加らは磁束速度が非常に不規則な值をとってい る。すなわち静から動，再び静から動上間欠的に磁束 加導体内侵入していることに対応していると考えら れる。我々の使用している導体では，ての50A は $0.0027 \mathrm{~T}$ (=27 ガウス) にあたり，導体中に存在する 200 本の心線中で起こるホッピングか, 心線間のそれ による音響かは現在のとてろ不明であるが，それらの 両方の共同現象と思われる。と屯かく，との計数率の 鋭い增減を繰返しながら, 通電電流を堌加するに往っ て磁束は最大磁界こう配すな切ち $I_{c}$ に近づくつ れ飽和状龍になり，磁束が動きが鈍化し， $\mathrm{AE}$ の計数 が最小となる。さていったん！。越した場合，ピン の制限を越えた電流に応じた自己磁束は，磁束流を形 成するので計数率の増加が著しくなる。更に通電が続 くと磁束流に上り導体温度が上昇し, 臨界電流密度 $J$ 。 に減少をきたす。この磁束分布とう配の鈍化化伴う磁

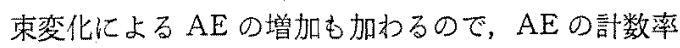
の增加に拍車がかかる。これは，磁束流状態でむ計数 率に鋭いピークが存在することから理解され，このて う配鈍化現象に伴う $A E$ の放出を繰返しながら常電導 転移してゅくと考えられる。

逆に，AE の計数率か一番静加になる上ころ，すな わち $\mathrm{AE}$ の計数率最小のところをるって試料の実磁界 上の臨界電流 $I c$ 上定義するととができる。本実験で は，乙の音響湘定による $I_{c}(\mathrm{AE})$ の方肪 $5 \times 10^{-12} \Omega$. $\mathrm{cm}$ の感度で計測した $I_{c}$ (抵抗) より, 約 $70 \mathrm{~A}$ 先行 
して検知している。このように音響測定からは $I_{f} の$ 絶対計測か河能となる。

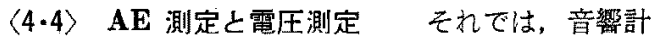
測の方が電圧測定より感度良く $I_{c}$ の測定や磁束の動 きを捕捉できるのであろうかということについては， 次のように推定される。てのような音響計测はパワ測 定であり，音王変化の平均 2 乘值(?)を測定しているの で，磁束の運動方向によらず各磁束が導体内を移動す れば，それに伴うパワ消費はひずみ波として伝わり， 音響索子はそのスカラー和を観測する。一方，電圧測 定によるものは各碰束の運動速度に比例する微小電圧 を，全導体内にわたってべクトル的に総和して観測す るものとされ，各磁束が加速・隇速を繰返して導体内 に侵入していくときは一種の雑音電圧として観測さ れ，微小なクリープ電圧はこれにマズクれる。すな わち，Icとして試料の端子電圧が情報をむたら卞のは 磁束がネットに定方向移動が相当進んだときである。 乙の場合, 測定感度にも依存するので一種の相対測定

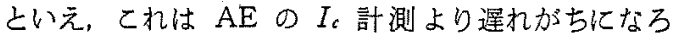
う。

〈4.5〉 AE と伝搬 超笔導導体と相対した銅材 の上に取り付けた素子でも，導電導体部の計測強度の 約1/10の強度で超電導導体と同じ傾向の AE が観測さ れた。すなわち，AE は銅ジャンパあるい忮支持体を 通して伝搬しており，てれは $\mathrm{AE}$ 素子の設置場所に相 当な余裕があるてとを意味する。なお，電流リード上 の素子には支持体のためであろうが，AE は観測され なかった。

\section{5.むすび}

以上の実験求よび検討の結果，次の事実が明らかに なった。

（1）超電導導体に外部磁界を印加守ると，この磁 化過程に伴う音響放出か超電導体内力ら観測される。 逆に，乙の音響放出に上り超雪導導体の磁化の進行状 況か測定される。特に臨界電流密度 $J$ 。の磁界依存性 が知られる。
（2）定磁界において通常電流を流す場合，乙の武 料の臨界電流值 $I_{c}$ を $\mathrm{AE}$ の計数率の変化加ら明膫化 検知でき，乙れは電圧法による $I_{c}$ が測定感度に依存 するのに比し，AE 法によるものは絶対 $I_{c}$ 測定と考 えられる。

（3）超電導遒体からの音響放出は，磁束のピン止 め域に蓄えられたひずみエネルギーが，磁束がその域 から擦り抜りるとき汇解放され，そのときひずみ波加 発生する。

（4）放出される音響周波数は，超電導体の構造上 で決まり，ほぼ一定周波数である（本実験の場合 250 . $\mathrm{kHz}$ 。

以上のととから，超電導導体自らが超音波音響を放 出していることが明確であり，このパワ強度を観測す ることにより超電導導体の磁化過程はむちろん, 通電 状態を監視できることがわかった。これらの音響法に よる計测は，磁束の運動が音場の信号に変換されてい るので電磁気系加らの雑音じょう乱に強く, 今後超電 導導体の特性解析研究に役立つと同時に大容量超電導 磁石の監視拉術の一助となれば幸いである。

終りに, この実験は Masschusetts Institute of Technology $\odot$ Francis Bitter National Magnet Laboratory の好意を得て研究できたものでありとてに 絶大な感謝の意を表します。また，ての研究を進める にあたり，同研究所のIwasa 博士の激励之有意義な ディスカッションを，また.Sinclair 氏には実験の援 助をいただきました。水冷マグネットの運転とエレタ トロニクスの徼協力を Rubin 氏, Albano 氏加らい ただきました。ここに心よりお礼申し上げます。

(昭和 54 年 5 月 7 日受付)

\section{文献}

(1) H. Nomura, et al. : Cryogenics, 17, 471 (1977)

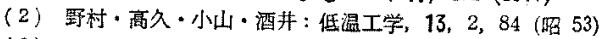

（3）尾上：会属斿料，10，94 (圆45)

(4) R.T. Sedgwick: J. Appl. Phys., 39, 1728 (1968)

(5) C.P. Bean: Phys. Rev. Letters, 11, 149 (1963)

(6) W.A. Fietz, et al.: Phys. Rev., No. 136 A, 335 (1964),

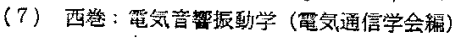

